\title{
Effects of dietary fat on cholesterol efflux and other cardiometabolic risk markers in humans
}

Citation for published version (APA):

van Rooijen, M. A. (2020). Effects of dietary fat on cholesterol efflux and other cardiometabolic risk markers in humans: focus on palmitic acid and stearic acid. [Doctoral Thesis, Maastricht University]. Gildeprint Drukkerijen. https://doi.org/10.26481/dis.20200701mr

Document status and date:

Published: 01/01/2020

DOI:

10.26481/dis.20200701mr

Document Version:

Publisher's PDF, also known as Version of record

\section{Please check the document version of this publication:}

- A submitted manuscript is the version of the article upon submission and before peer-review. There can be important differences between the submitted version and the official published version of record.

People interested in the research are advised to contact the author for the final version of the publication, or visit the DOI to the publisher's website.

- The final author version and the galley proof are versions of the publication after peer review.

- The final published version features the final layout of the paper including the volume, issue and page numbers.

Link to publication

\footnotetext{
General rights rights.

- You may freely distribute the URL identifying the publication in the public portal. please follow below link for the End User Agreement:

www.umlib.nl/taverne-license

Take down policy

If you believe that this document breaches copyright please contact us at:

repository@maastrichtuniversity.nl

providing details and we will investigate your claim.
}

Copyright and moral rights for the publications made accessible in the public portal are retained by the authors and/or other copyright owners and it is a condition of accessing publications that users recognise and abide by the legal requirements associated with these

- Users may download and print one copy of any publication from the public portal for the purpose of private study or research.

- You may not further distribute the material or use it for any profit-making activity or commercial gain

If the publication is distributed under the terms of Article $25 \mathrm{fa}$ of the Dutch Copyright Act, indicated by the "Taverne" license above, 


\section{Summary}

Coronary heart disease (CHD), also known as coronary artery disease (CAD) or ischemic heart disease (IHD), is a common type of cardiovascular disease (CVD) and a major cause of death worldwide. CHD is caused by a disrupted blood flow to the heart due to the development of an atherosclerotic plaque in the coronary arteries. LDL-cholesterol is a well-established risk factor for CHD, as high concentrations are positively and causally related to CHD. In contrast to LDL-cholesterol, high concentrations of HDL-cholesterol have been associated with a reduced risk for CHD. However, recent drug interventions that increased HDL-cholesterol failed to reduce this risk. Thus, $\mathrm{HDL}$-cholesterol is not causally related to $\mathrm{CHD}$ and it is now believed that we should focus on HDL functionality instead of the concentration of HDLcholesterol. One of the functionalities of HDL is its capacity to perform cholesterol efflux from lipid-loaded macrophages, known as cholesterol efflux capacity (CEC). Indeed, cholesterol efflux mediated via ATP-binding cassette transporter A1 (ABCA1-mediated CEC) has been inversely associated with CHD-risk. For ABCA1-mediated CEC, interaction between ABCA1 (present on many cells including macrophages) and apolipoprotein A-I (apoA-I; component of $\mathrm{HDL}$ ) is crucial. Besides, also other fasted and postprandial markers are known to be relevant for the risk of developing $\mathrm{CHD}$, such as those related to lipemia, glucose-insulin homeostasis, low-grade inflammation and/or endothelial function.

Diet and other lifestyle factors such as exercise or smoking affect the risk of developing atherosclerosis and subsequent CHD. One of the dietary factors that has been linked to CHDrisk is saturated fat, because the intake of saturated fat is positively associated with fasted serum LDL-cholesterol concentrations. However, saturated fat is an umbrella term for different saturated fatty acids that may exert different effects on LDL-cholesterol and other CHD-risk markers. Indeed, it is well-known that the two most abundant saturated fatty acids in many Western diets, palmitic acid (C16:0) and stearic acid (C18:0), differently affect cholesterol concentrations, i.e. stearic acid lowers LDL- and HDL-cholesterol compared with palmitic acid. However, it is less clear whether these fatty acids also differently affect other risk markers such as cholesterol efflux. Therefore, the research in this dissertation is mainly focused on the effects of dietary fat - predominantly the saturated fatty acids palmitic acid and stearic acid - on conventional and emerging cardiometabolic risk markers among which ABCA1-mediated CEC. For this, the results of a systematic review and two human dietary intervention studies have been described in this dissertation.

In chapter 2, existing literature describing the effects of stearic acid-versus palmitic acid-rich fats on cardiometabolic risk markers has been reviewed. In addition, it was also examined whether interesterification (shuffling fatty acids between and within triacylglycerols) of palmitic acid- or stearic acid-rich fats affects these risk markers, because interesterification is nowadays widely used by the food industry to increase the suitability of fats for certain 
foods. Indeed, it was found that substituting palmitic acid with stearic acid lowers fasted serum LDL- and HDL-cholesterol. Interesterification of palmitic acid- or stearic acid-rich fats does not differently affect fasted lipids and (apo)lipoproteins when compared to their corresponding non-interesterified (native) fats. However, during the postprandial phase, lipemia is attenuated if the solid fat content of the fat blend at $37^{\circ} \mathrm{C}$ is increased by interesterification due to changes in palmitic acid or stearic acid sn-2 contents, while no evidence was found that solely substituting palmitic acid with stearic acid affects postprandial lipemia. How palmitic acid- or stearic acid-rich fats as well as interesterification of these fats affects other cardiometabolic risk markers needs further investigation before conclusions could be drawn.

In chapters 3, 4 and 5, the results of a human dietary intervention study with twenty men and fourteen postmenopausal women are described to examine longer-term and postprandial effects of palmitic-acid versus stearic-acid intakes on cholesterol efflux and other cardiometabolic risk markers.

The longer-term effects of 4-week diets rich in palmitic acids or stearic acids on cardiometabolic risk markers are reported in chapter 3. As expected, stearic-acid intake lowered fasted LDL- and HDL-cholesterol compared with palmitic-acid intake. ABCA1mediated CEC was however comparable between the two diets, even though apoA-I concentrations were also lower on the stearic-acid diet. The lower HDL-cholesterol concentrations may at least partly be explained by an increased mass of cholesteryl ester transfer protein (CETP). In addition, the results suggest that insulin sensitivity in women as well as low-grade inflammation in both men and women might be unfavorably affected by stearic-acid intake.

In chapter 4, results of the postprandial tests performed at the end of both dietary intervention periods are described. Participants received two consecutive mixed meals high in palmitic acid- or stearic acid-rich fat blends during each postprandial test and effects on postprandial lipemia and glycemia were studied. Consumption of the meals containing the stearic acid-rich fat lowered postprandial lipemia as compared with the palmitic-acid meals. In addition, our results indicate that the number of chylomicrons after intake of the stearicacid meals was lower. It is hypothesized that these observed differences are due to the higher solid fat content of the stearic acid-rich fat at $37^{\circ} \mathrm{C}$. As triacylglycerol-rich lipoproteins are positively related to $\mathrm{CHD}$, the effects of stearic acid on postprandial lipemia appear to be more favorable than those of palmitic acid. No pronounced differences in parameters related to postprandial glycemia were found between the fatty acids, although the changes over time in C-peptide - a marker of insulin secretion - differed. C-peptide concentrations were higher after the first stearic acid-rich meal and peaked earlier after the second stearicacid rich meal when compared with the palmitic acid-rich meals. In addition, concentrations of non-esterified fatty acids (NEFA) were markedly lower after intake of the stearic acid-rich 
fats. It is hypothesized that lower postprandial NEFA concentrations are more favorable, but a direct link between NEFA and CHD-risk has not been established so far.

Results of the 4-week diets on fasted lipoprotein subfractions, and fasted and postprandial apoA-I concentrations, apoA-I secretion and ABCA1-mediated CEC can be found in chapter 5 . These results indicate that palmitic-acid and stearic-acid diets differently affect cholesterol and triacylglycerol concentrations in several VLDL, LDL, and HDL subfractions. Cholesterol concentrations on the stearic-acid diet were higher in subfractions of VLDL and lower in those of LDL and HDL compared with the palmitic-acid diet. On the other hand, triacylglycerol concentrations were higher in VLDL, LDL, and HDL subfractions on the stearicacid diet. As triacylglycerol concentrations within lipoprotein subfractions have been positively associated with cardiovascular disease, this appears to be an unfavorable effect of stearic acid. No significant differences between the diets were found in fasted and postprandial ABCA1-mediated CEC as well as apoA-I secretion, although fasted apoA-I concentrations were lower on the stearic-acid diet.

Lastly, we have compared in eighteen men the effects of acute consumption of high-fat, high-protein, or high-carbohydrate meals on postprandial ABCA1-mediated CEC and (secretion of) apoA-I. These results are reported in chapter 6 . We did not observe any differences between the meals in postprandial ABCA1-mediated CEC and apoA-I concentrations, even though the high-protein and high-fat meals increased apoA-I secretion.

In summary, the research in this dissertation was performed to get more insight into the effects of dietary fat, particularly the two most commonly consumed saturated fatty acids palmitic acid and stearic acid, on conventional and emerging cardiometabolic risk markers, with an emphasis on ABCA1-mediated CEC. Our findings have shown that palmitic acid and stearic acid have comparable effects on ABCA1-mediated CEC, but differently affect several other fasting and postprandial cardiometabolic risk markers. Thus, at this moment it cannot be excluded that palmitic acid and stearic acid differently affect cardiometabolic health via mechanisms other than LDL-cholesterol. In addition, no evidence was found that acute intakes of high-fat, high-protein or high-carbohydrate meals differently affect postprandial ABCA1-mediated CEC. 


\section{Nederlandse samenvatting}

Coronaire hartziekten ( $\mathrm{CHZ}$ ), ook wel bekend als ischemische hartziekten, zijn de meest voorkomende hart- en vaatziekten en een veelvoorkomende oorzaak voor sterfte wereldwijd. $\mathrm{CHZ}$ worden veroorzaakt door een verminderde bloedtoevoer naar het hart vanwege aderverkalking (atherosclerose) in de coronaire slagaderen. Een welbekende risico factor voor $\mathrm{CHZ}$ is LDL-cholesterol, omdat hoge concentraties positief en causaal gerelateerd zijn aan $\mathrm{CHZ}$. Naast LDL-cholesterol zijn er ook andere markers gerelateerd aan het risico op $\mathrm{CHZ}$. Hoge concentraties HDL-cholesterol zijn bijvoorbeeld geassocieerd met een verlaagd risico op $\mathrm{CHZ}$. Desalniettemin is het met recente farmacologische interventies die HDLcholesterol verhogen niet gelukt om het $\mathrm{CHZ}$-risico te verlagen. Daaruit is gebleken dat $\mathrm{HDL}$ cholesterol niet causaal gerelateerd is aan $\mathrm{CHZ}$ en wetenschappers denken nu dat de functionaliteit van de HDL-deeltjes belangrijker is dan de hoeveelheid HDL-cholesterol. Een van de functies van HDL is het accepteren van cholesterol uit lipide-rijke macrofagen, dit noemen we cholesterol efflux capaciteit (CEC). Cholesterol efflux via ATP-bindende cassette transporter $\mathrm{A} 1$ ( $\mathrm{ABCA1-gemedieerde} \mathrm{CEC}$ ) is negatief geassocieerd met het risico op $\mathrm{CHZ}$. Voor ABCA1-gemedieerde CEC is interactie tussen ABCA1 (aanwezig op verschillende cellen waaronder macrofagen) en apolipoproteïne A-I (apoA-I; onderdeel van HDL) cruciaal. Daarnaast zijn ook andere nuchtere en postprandiale biomarkers relevant voor het risico op $\mathrm{CHZ}$, zoals markers gerelateerd aan lipemie, glucose-insuline homeostase, lichte ontsteking en/of endotheel functie.

Dieet en overige leefstijlfactoren zoals sporten en roken hebben invloed op het risico om aderverkalking te ontwikkelen, wat weer kan leiden tot $\mathrm{CHZ}$. Een van de factoren uit het dieet gelinkt aan het risico op $\mathrm{CHZ}$ is verzadigd vet, omdat de inname van verzadigd vet positief geassocieerd is met nuchtere serum LDL-cholesterol waarden. Verzadigd vet is echter een verzamelnaam voor verschillende verzadigde vetzuren die mogelijk verschillende effecten hebben op LDL-cholesterol en andere risicomarkers voor $\mathrm{CHZ}$. Het is inderdaad bekend dat de twee meest voorkomende verzadigde vetzuren in menig Westers dieet, palmitinezuur (C16:0) en stearinezuur (C18:0), verschillende effecten hebben op het cholesterolgehalte. Stearinezuur verlaagd namelijk LDL- en HDL-cholesterol ten opzichte van palmitinezuur. We weten echter nog niet zo goed of deze vetzuren ook verschillende effecten hebben op andere risicomarkers zoals cholesterol efflux. Daarom ligt de focus van het onderzoek beschreven in dit proefschrift op de effecten van voedingsvet - voornamelijk de verzadigde vetzuren palmitinezuur en stearinezuur - op cardiometabole risicomarkers waaronder ABCA1-gemedieerde CEC. Hiervoor hebben we de resultaten van een systematische review en twee humane interventies studies beschreven. 
In hoofdstuk 2 is de bestaande literatuur over de effecten van vetten rijk aan stearinezuur versus vetten rijk aan palmitinezuur op cardiometabole risicomarkers besproken. Daarnaast is er ook gekeken of interesterificatie (uitwisselen van vetzuren tussen en binnen triglyceriden) van palmitine- of stearine-rijke vetten een effect heeft op deze risicomarkers, omdat interesterificatie momenteel veel wordt gebruikt door de voedingsindustrie om de toepasbaarheid van vetten te verhogen voor bepaalde voedingsmiddelen. Zoals verwacht verlaagd vervanging van palmitinezuur door stearinezuur de nuchtere serum concentraties van LDL- en HDL-cholesterol. Interesterificatie van vetten rijk in palmitinezuur of stearinezuur had geen effect op nuchtere lipiden en (apo)lipoproteïnen. Daarentegen was postprandiale lipemie verminderd als door interesterificatie de veranderingen in de hoeveelheid palmitine- of stearinezuur op sn-2 het gehalte aan vast vet bij $37^{\circ} \mathrm{C}$ verhoogden. Er was echter geen bewijs dat enkel het vervangen van palmitinezuur door stearinezuur een effect heeft op postprandiale lipemie. Er is meer onderzoek nodig om conclusies te trekken over de effecten van (interesterificatie van) vetten rijk aan stearinezuur of palmitinezuur op andere cardiometabole risicomarkers.

In hoofdstuk 3, 4 en 5 zijn de resultaten beschreven van een humane voedingsinterventie studie met twintig mannen en veertien postmenopauzale vrouwen waarin zowel de langeretermijn als postprandiale effecten van de inname van palmitinezuur versus stearinezuur op cholesterol efflux en andere cardiometabole risicomarkers zijn bestudeerd.

De langere termijneffecten van een 4-weken dieet rijk in palmitinezuur of stearinezuur op cardiometabole risicomarkers zijn gerapporteerd in hoofdstuk 3 . Zoals verwacht verlaagde de inname van stearinezuur nuchtere LDL- en HDL-cholesterol waarden vergeleken met de inname van palmitinezuur. Echter was er ondanks de verlaging van $\mathrm{HDL}-$ cholesterol en apoA-I-concentraties op het stearine-dieet geen verschil in ABCA1gemedieerde CEC tussen de diëten. De lagere HDL-cholesterol concentraties kunnen mogelijk verklaard worden door de hogere hoeveelheid cholesterylestertransferproteïne (CETP). Daarentegen waren zowel insulinegevoeligheid in vrouwen als inflammatiewaarden in de gehele populatie mogelijk negatief beïnvloed door het stearine-dieet.

In hoofdstuk 4 zijn de resultaten van de postprandiaal testen aan het eind van beide voedingsinterventies beschreven. Deelnemers kregen twee opeenvolgende maaltijden rijk aan palmitinezuur of stearinezuur tijdens elke postprandiaal test en de effecten op postprandiale lipemie en glycemie zijn bestudeerd. Inname van de maaltijden rijk aan stearinezuur verlaagde postprandiale lipemie vergeleken met de maaltijden rijk aan palmitinezuur. Daarbij laten de resultaten ook zien dat er minder chylomicronen waren na inname van de stearine-rijke maaltijden. De hypothese is dat deze verschillen veroorzaakt worden door het hogere gehalte aan vast vet in het stearine-rijke vet bij lichaamstemperatuur. Aangezien triglyceride-rijke lipoproteïnen positief gerelateerd zijn aan $\mathrm{CHZ}$, lijken de effecten van stearinezuur op postprandiale lipemie gunstiger te zijn dan die 
van palmitinezuur. Er waren geen uitgesproken verschillen waarneembaar in markers gerelateerd aan postprandiale glycemie, al waren de veranderingen over tijd in C-peptide een marker voor insuline secretie - verschillend tussen de vetzuren. De concentratie Cpeptide was hoger na de eerste stearine-rijke maaltijd en piekte eerder na de tweede stearine-rijke maaltijd ten opzichte van de palmitine-rijke maaltijden. Daarbij was de concentratie vrije vetzuren sterker verlaagd na inname van de stearine-rijke maaltijden. De hypothese is dat lagere postprandiale vrije vetzuren gunstiger zijn, maar een directe link tussen vrije vetzuren en het risico op $\mathrm{CHZ}$ is tot op heden niet vastgesteld.

Resultaten van de 4-weken diëten op nuchtere lipoproteïnen subfracties alsmede op nuchtere en postprandiale apoA-I waarden, apoA-I secretie en ABCA1-gemedieerde CEC zijn gerapporteerd in hoofdstuk 5. Deze resultaten laten zien dat diëten rijk aan palmitine of stearinezuur verschillende effecten hebben op nuchtere cholesterol en triglyceride concentraties in meerdere VLDL, LDL en HDL subfracties. Cholesterolwaarden tijdens het stearine-dieet waren hoger in subfracties van VLDL en lager in subfracties van LDL en HDL vergeleken met het palmitine-dieet. Daarentegen waren de triglyceride concentraties in VLDL, LDL en HDL subfracties hoger op het stearine-dieet. Aangezien triglyceride concentraties binnen lipoproteïne subfracties positief geassocieerd zijn met hart- en vaatziekten, lijkt dit een ongunstig effect van stearinezuur. Er zijn geen significante verschillen gevonden tussen diëten in nuchtere en postprandiale ABCA1-gemedieerde CEC alsmede apoA-I secretie, ondanks dat nuchtere apoA-I concentraties lager waren op het stearine-dieet.

Tot slot hebben we in achttien mannen de effecten vergeleken van de acute consumptie van hoog-vet, hoog-eiwit of hoog-koolhydraat maaltijden op postprandiale ABCA1-gemedieerde CEC en (secretie van) apoA-I. Deze resultaten zijn beschreven in hoofdstuk 6. Er zijn geen verschillen gevonden tussen de maaltijden wat betreft serum ABCA1-gemedieerde CEC en apoA-I concentraties, terwijl de hoog-vet en hoog-eiwit maaltijden apoA-I secretie verhoogden.

Het onderzoek in dit proefschrift was uitgevoerd om meer inzichten te krijgen in de effecten van voedingsvetten, voornamelijk de twee meest geconsumeerde verzadigde vetzuren palmitinezuur en stearinezuur, op een breed scala aan cardiometabole risicomarkers, met de nadruk op ABCA1-gemedieerde CEC. Onze bevindingen hebben laten zien dat palmitinezuur en stearinezuur vergelijkbare effecten hebben op ABCA1-gemedieerde CEC, maar verschillende effecten hebben op een verscheidenheid aan andere nuchtere en postprandiale cardiometabole risicomarkers. Op dit moment kan het dus niet uitgesloten worden dat palmitinezuur en stearinezuur verschillende effecten hebben op de cardiometabole gezondheid via mechanismes niet gerelateerd aan LDL-cholesterol. 
Daarnaast laat het onderzoek in dit proefschrift zien dat er geen verschillen zijn tussen innames van hoog-vet, hoog-eiwit of hoog-koolhydraat maaltijden in postprandiale ABCA1gemedieerde CEC. 